\title{
Indonesia COVID-19 Task Force Statement Framing in September - November 2020
}

\author{
http://dx.doi.org/10.25008/jkiski.v6i1.505
}

\author{
Mutiara Nabila \\ Department of Communication, Universitas Indonesia \\ Jl. Salemba Raya No. 4, Jakarta 10430 - Indonesia \\ Corresponding author: mutiara.nabila81@ui.ac.id
}

Submitted: March 13, 2021, Revised: April 19, 2021, Accepted: June 09, 2021

Accredited by Kemristekdikti No. 28/E/KPT/2019

\begin{abstract}
This study aims at examining how Indonesia COVID-19 Task Force, as the government's right hand man, uses Framing Theory in the press statement contents, to convince the public that the handling of COVID-19 in Indonesia has been good enough. The analysis was carried out on the content of the COVID-19 Task Force press statement from September to November 2020 when there were spikes in COVID-19 cases during that period. This research uses the social construction paradigm, to find out what kind of news framing is being carried out by the COVID-19 Handling Task Force related to news about the COVID-19 case through Murray Edelman's framing analysis. By using Murray Edelman's framing analysis, this study tries to reveal the framing of the press release of the COVID-19 Handling Task Force to form a direct public understanding that the handling of COVID-19 in Indonesia is well. The results of the analysis showed that the positive COVID-19 handling task force used a categorization framing with the titles of press statements, the majority of which only mentioned about the recovery of COVID-19 patients, such as: The Number of COVID-19 Patients Continues to Increase to 429,807 People; COVID-19 Testing Results Show 86\% Confirmed Negative; Number of Testing Week Third of November Approaches WHO Standards.
\end{abstract}

Keywords: Framing; content; categorization; COVID-19; communication.

\section{Introduction}

In doing publicity and coverage, the government has ways of communicating progress and the progress made. To communicate the results of its work, the government uses Public Relations to connect public interaction with the government, regulators, and as an additional hand to convey government policies.

Government public relations can be in the form of spokespersons. According to McNair (2011), a spokesperson is a man or woman who has the competence to become a representative of a political actor or organization and has the authority to speak. Meanwhile, according to Seitel (2015), a spokesperson is not just a mouthpiece, but he must also trust the decisions made by his leader.

The agenda setting theory also mentions one of the spokesperson's duties. Agenda setting was first introduced by McCombs and Shaw when researching presidential campaigns in the United States in 1968, 1972, and 1976 (University of Twente, 2019). The essence of the assumption of this theory is that the information conveyed in the mass media can consistently influence the public, so that it considers the issue to be important. Furthermore, what is not considered important and is not shown in the media will immediately escape the public eye. In implementing the agenda setting, each information must go 
through a framing process. This is done in order to achieve the desired reputation and image.

Sallot dan Johnson (2006) Sallot and Johnson (2006) explained that the news broadcast by the media mostly comes from the information provided by the spokesperson to the media. PR has the power to influence the media agenda, which is actually the editorial prerogative of each media (Alvin, 2020).

In previous study by Alvin (2020), it is stated that the Vice President also uses government public relations (GPR) or government public relations, which is in charge of conveying information about government policies and also listening to and absorbing the aspirations of the public. Government public relations is needed for the purposes of building and maintaining a positive self-image, so that the government can run well. This can be realized if there is good communication between the government and the community, so that both parties understand each other and lead to support from the community to the government (Alvin, 2020).

During this times of pandemic, a study by Wang, Hao, and Sundahl (2021) also stated that The World Health Organization (WHO) and the U.S. federal and state health agencies (agencies hereafter) and other federal agency build stakeholders whose operations are related to stemming the COVID-19 outbreak have consecutively published virus and diseaserelated content through their social media such as Twitter accounts. These actors' crisis and risk communication can provide credible sources of information during the unfolding of a crisis. The stakeholders that hold the Twitter account can be used to predominated information as the trusted sources, and they can also suppress the propagation of rumors (Wang et al., 2021).

In handling COVID-19 in Indonesia, the government formed a COVID-19 Handling Task Force, which was also represented by a number of spokesmen to publish. One of the publications is done using digital press releases via the Covid19.go.id website. The site is used by the COVID-19 Handling Task Force as a media, to routinely deliver messages to the public (Akil, 2014).

This routine information is disseminated through press releases. According to Iriantara (2005), press releases are basically news, so in writing press releases, the public relations or public relations department must see what is going to be written from the perspective of the journalist. This is because the press release will eventually be sent to the mass media whose content is generally not controlled by management (Hardian, 2018).

Press releases themselves (in Ruslan, 2002) are said to be very much needed by an institution, especially government agencies. Because it is the same as news, the spokesperson and the public relations department of an institution need to master the basics of news writing techniques, including for the production of press releases, articles or features (Hardian, 2018).

Iriantara (2005) also stated that things that must be considered in writing press releases other than journalistic language are completeness in answering six popular questions abbreviated as $5 \mathrm{~W}+1 \mathrm{H}$ (what, why, where, when, who, how). The content of the news is made into an inverted triangle or pyramid, where information that is considered important and news value must be placed in the initial paragraph (Asteria, 2014).

The initial part of the news is often referred to as the news terrace or lead which is divided into several types. In addition, the element of news value is also a consideration in writing a press release because it determines whether the press release is appropriate or not to be published in the mass media, especially newspapers (Hardian, 2018).

\section{Theoretical Framework}

In the manufacture of this news, there is a huge role between journalists and PR officers who then can bring up the news framing (framing). According to Scheufele and Tewksbury (2007), framing is news based on assumptions related to an important issue, categorized as news, and has an influence on the reader's understanding. Journalists use framing given from PR through press releases to find out the storyline, thematic, style, and facts when making news or raising an issue, which will lead to public opinion (Lee \& Basnyat, 2013).

Scheufele (2000) states that framing by the media can later shape readers' feelings or thoughts about an issue. Based on cognitive psychology, Price \& Tewksbury, (1997) said that framing relies on the associative network model of human memory, in which ideas, feelings, or concepts are stored in a knot and linked to others through semantic channels. (Lee \& Basnyat, 2013).

The media framing on the news will later function as a filter to activate certain ideas, feelings or concepts and for further information processing or the formation of judgments. It can 
also provoke predictable reactions from individuals (Ahern \& Sosyura, 2014).

Associated with framing, some experts define the notion of framing, one of which Murray Edelman (1993) says that the framing is what we know about reality or about the world depends on how we frame and construct or interpret reality. The same reality may produce different realities when the reality is framed or constructed in different ways (Fathururrahim, 2017).

In analyzing a news text, Murray Edelman has four methods to examine more deeply, namely categorization, ideology, rubrics, and classification (Fathururrahim, 2017). The first one is categorization.

To assist humans in understanding reality or facts, Edelman aligned framing with categorization. The use of certain words indicates how facts or reality are understood. Categories are very helpful in an irregular reality that becomes regular and has meaning. Categorization can also mean a simplification, complex and dimensional reality is understood and emphasized on one side or dimension so that other dimensions of one event or fact are not covered. (Fathururrahim, 2017)

Categorization is an act of thought in the form of using certain perspectives to understand a reality. The process of categorization requires the use of certain words by which reality will be understood. Categorization, in Edelman's view, is an abstraction and a function of the mind (Mark, Julie, \& Bonnie, 1998). Events, people, or groups are given meaning in a framework or scheme. With this framework, an individual puts every incident, event, person, or group in a structured and coherent story line. Without this framework, events will appear chaotic, confusing, and meaningless, and events will appear to be independent and disconnected. Categories help humans understand the diverse and irregular reality into a meaningful reality (Rohmatullah, 2017).

In media reporting, categorization becomes very important, in the categorization of an event, it is generally followed up by referring to the category in question, so in making questions, quotations to be taken, and data which must be discarded already exist in the categorization that has been made. With audience categorization, they are able to see those who want to benefit themselves and bring others down (Aryadi, 2014).

In seeing events must have a broad view, a reality must be studied deeply. The current reality could have been entered into the ideology of someone who took sides on one side, and made the public believe in raw reality (Robbins, 2020).

Second, tis ideology. The use of categorization, such as regulation, defense, elections, etc., should not be understood solely as a technical linguistic problem, but rather as an ideological problem. Categorization is related to ideology, in the meaning of categorization examines in depth, not only in terms of language use, but is able to distinguish between a discussion or ideology of a party, because by knowing the ideology, it is clear which direction the news is categorized.

Reymond William (2011) in Imas Damayanti (2013), has the idea that ideology is a false belief system or false ideas, ideology in this sense is a set of categories created and false awareness where the dominant group uses to dominate other groups that are not dominant. The meaning of a text must be understood more deeply, it could be that the meaning that is expressed in the midst of the audience is the ideology of a group with certain aims and objectives, then the true meaning is lost when an ideology has entered.

Third, Rubrics. According to Edelman, rubrics must be understood not merely as a technical issue or standard procedures for news production. It must be understood as part of how facts are classified into certain categories. Rubrics determines how the phenomenon is to be described. In making news, it must be in accordance with the relevant rubric, so that there is no mis-categorization. So it is not uncommon for the media to put the rubric and news wrong, making the audience's view follow what the media says about the news in that rubric, although it is trivial but has a big impact on the audience in placing the news in the right rubric. (Fathururrahim, 2017)

Rubrics is the use of categories in seeing various events so that it requires a classification of the various observed events. Technically, classification relates to how an event is understood and communicated. Rubrics is also a manifestation of the process of categorizing thoughts in reporting. Therefore, Edelman stated that classification determines the growth of public support or even opposition.

For example, the occurrence of public support or opposition to a government policy is determined by the way an event is presented and communicated to the public. It is in the process of presenting and communicating events that categorization and classification work in the mind. The use of certain categories and 
categories can lead the public to support or reject (Rohmatullah, 2017).

Then, lastly classification. Murray Edelman (1993) in Eriyanto (2002) states that classification determines and affects political support or opposition. Classification determines and influences the audience's emotions when viewing or seeing an event. The existence of categories and classifications, can help audiences to perceive reality. Classification and categorization are closely related to how reality is understood and understood or what the audience should emphasize in seeing an event or reality. One of Edelman's ideas is to be able to direct the view of the audience on an issue and shape their understanding of an issue. The view of an event is therefore limited only by the debates that have been determined in the categorization (Fathururrahim, 2017).

\section{Material and Methodology}

This research uses the social construction paradigm, to find out what kind of news framing is being carried out by the COVID-19 Handling Task Force related to news about the COVID19 case through Murray Edelman's framing analysis (categorization, ideology, rubrics, and classification) (Launa, 2020). Meanwhile, this type of research uses a descriptive-interpretive approach by analyzing press releases on the
Covid19.go.id page, to get an overview and meaning of how the COVID-19 Handling Task Force provides information related to COVID19 to the media and the public (Thorne, Kirkham, \& Flynn, 2004).

The interpretive description approach is used to provide a logical structure and a philosophical rationale for answering qualitative questions, because the interpretive description approach provides the foundation for conceptual relationships that explain specific things in terms of general, process, and subjectivity (Lambert \& Lambert, 2012).

Interpretive analysis is used because this approach views news as something dynamic and subjective, and interprets the news text as a reality of social construction results (journalist interpretation / media interpretation). Interpretive analysis believes that journalists / media as interpreting actors have certain awareness and motives (Rahardjo, 2018).

Regarding the object of analysis, based on the author's observations, there are 25 articles from the COVID-19 Handling Task Force from September to November 2020 which focus on the recovery of COVID-19 patients when at the same time, the increase in confirmed cases of COVID-19 is high. From the 25 articles, two samples were taken from each of the months of September, October, and November.

Table 1. Covid19.go.id Articles September - November 2020

\begin{tabular}{|l|l|l|}
\hline September 2020 & October 2020 & November 2020 \\
\hline $\begin{array}{l}\text { Indonesia's COVID-19 Recovery } \\
\text { Rate is Above the World Average } \\
\text { (September 2020) } \\
\text { (Covid19.go.id, 2020e). }\end{array}$ & $\begin{array}{l}\text { Patients Recovered Pass the } \\
\text { Figures 225,052 Cases (October 3 } \\
\text { 2020) (Covid19.go.id, 2020e) }\end{array}$ & $\begin{array}{l}\text { The Number of COVID-19 } \\
\text { Patients Continues to Increase to } \\
429,807 \text { People (November 25 } \\
\text { 2020) (Covid19.go.id, 2020c) }\end{array}$ \\
\hline $\begin{array}{l}\text { Recovered Patients Reached } \\
\begin{array}{l}\text { 152,458 Cases (September 12 } \\
\text { 2020) (Covid19.go.id, 2020d). }\end{array}\end{array}$ & $\begin{array}{l}\text { COVID-19 Testing Results Show } \\
\text { 86\% Confirmed Negative (Oktober } \\
\text { 19th 2020) (Covid19.go.id, 2020a) }\end{array}$ & $\begin{array}{l}\text { Number of Testing Week Third } \\
\text { November Approaches WHO } \\
\text { Standards (November 24 2020) } \\
\text { (Covid19.go.id, 2020b) }\end{array}$ \\
\hline
\end{tabular}

The data collection technique used in this study is the documentation technique (study in documents) by collecting primary data collection in the form of news texts on Covid19.go.id. The collected data is then classified and analyzed using qualitative analysis techniques (descriptive-interpretive).

Other data sources used or secondary data and tertiary data, use other articles that show conditions are inversely proportional to the statements in the selected articles, and use books, journals, and other written sources relevant to the needs of the study.
Furthermore, the data analysis technique was carried out through the stages of data collection and classification, identification and categorization of data matched into analysis units, interpretation and analysis of the text of press release articles using Murray Edelman framing analysis, and drawing conclusions.

\section{Result and Discussion}

In September 2020, there was a spike in COVID-19 cases in Indonesia as a result of the long holiday on Independence Day on August 17 and the Islamic New Year holidays from 20- 
21 August 2020. According to the Spokesperson for the COVID-19 Task Force, a spike in COVID-19 cases could occur during holidays as people flock to vacation spots with decreased levels of adherence to health protocols. The impact of the crowds that occur during the holiday period will generally only be felt in the next 2-3 weeks.

Starting in the second week of September, for the first time Indonesia has received more than 3,000 additional COVID-19 cases a day. On the other hand, the COVID-19 Handling Task Force broadcasts news that only focuses on the recovery of COVID-19 patients. This pattern of writing press releases has been used since the beginning of the pandemic, which was admitted by the Spokesperson for the COVID19 Handling Task Force so that people do not panic and fear facing the COVID-19 pandemic.

Based on the classification results of the press release text, six texts were selected purposively for analysis related to framing conducted by the COVID-19 Handling Task Force during September - November 2020. The titles of the six news stories can be analyzed in terms of news framing as follows.

Table 2. COVID-19 Handling Task Force Press Releases on September 2020

\begin{tabular}{|c|c|c|c|c|}
\hline Title & Categorization & Ideology & Rubrication & Classification \\
\hline $\begin{array}{l}\text { Indonesia's } \\
\text { COVID-19 } \\
\text { recovery rate is } \\
\text { above the world } \\
\text { average } \\
\text { September 2020). }\end{array}$ & $\begin{array}{l}\text { - Title: Indonesia's } \\
\text { COVID-19 } \\
\text { recovery rate is } \\
\text { above the world } \\
\text { average } \\
\text {-Lead: The number } \\
\text { of active cases in } \\
\text { Indonesia is still } \\
\text { better than the } \\
\text { world average, seen } \\
\text { as of } 1 \text { September } \\
2020 . \text { In Indonesia } \\
\text { the number is } \\
42,009 \text { cases with a } \\
\text { percentage of } \\
23.7 \% \text {, while the } \\
\text { world average is at } \\
26.6 \% \text {. } \\
\text { - (Spokesperson for } \\
\text { the Task Force) } \\
\text { "The same thing } \\
\text { was found in the } \\
\text { recovery rate which } \\
\text { reached } 128,057 \\
\text { cases or } 72.1 \% \text {. } \\
\text { This figure is better } \\
\text { and still above the } \\
\text { world average of } \\
69.97 \% \text {. }\end{array}$ & $\begin{array}{l}\text { - Paragraph } 2 \text { : the } \\
\text { recovery rate which } \\
\text { reached } 128,057 \\
\text { cases or } 72.1 \% \text {. } \\
\text { This figure is better } \\
\text { and still above the } \\
\text { world average of } \\
69.97 \%\end{array}$ & $\begin{array}{l}\text { The task force } \\
\text { directs readers to } \\
\text { accept the good } \\
\text { news first. You can } \\
\text { see the framing } \\
\text { carried out by the } \\
\text { Task Force in this } \\
\text { article, starting the } \\
\text { news with good } \\
\text { news, hoping that } \\
\text { what the readers } \\
\text { will absorb is good } \\
\text { news. } \\
\text { Bad news is put at } \\
\text { the bottom of the } \\
\text { news. In news } \\
\text { writing, generally } \\
\text { the bottom section } \\
\text { only contains } \\
\text { additional } \\
\text { information and is } \\
\text { in a less important } \\
\text { position for the } \\
\text { reader. }\end{array}$ & $\begin{array}{l}\text { Through this article, } \\
\text { the Task Force } \\
\text { hopes that readers } \\
\text { will be more } \\
\text { confident in the } \\
\text { Task Force's } \\
\text { performance in } \\
\text { handling } \\
\text { COVID-19 } \\
\text { pandemic. That the } \\
\text { Task } \\
\text { succeeded Force } \\
\text { inviting the public } \\
\text { to help improve } \\
\text { recovery, that } \\
\text { COVID-19, the } \\
\text { COVID-19 cases } \\
\text { were under control, } \\
\text { and the majority of } \\
\text { cases could recover. }\end{array}$ \\
\hline $\begin{array}{lr}\text { Recovered } & \text { Patients } \\
\text { Reached } & 152,458 \\
\text { Cases } & (12 \\
\text { September } & 2020) .\end{array}$ & $\begin{array}{l}\text { - Title: Recovered } \\
\text { Patients Reached } \\
\text { 152,458 Cases } \\
\text { - News Agency: } \\
\text { Recovery rate for } \\
\text { COVID-19 patients } \\
\text { as of } 12 \text { September } \\
2020 \text { increased by } \\
2,241 \text { cases. The } \\
\text { total number of } \\
\text { recovered patients } \\
\text { nationwide has now } \\
\text { reached 152,458 } \\
\text { cases. }\end{array}$ & $\begin{array}{l}\text { - Statement: In } \\
\text { addition, from the } \\
\text { details of the top } \\
\text { three cases per } \\
\text { province, DKI } \\
\text { Jakarta added the } \\
\text { most patients } \\
\text { recovered daily } \\
\text { with } 665 \text { cases and } \\
\text { the cumulative } \\
\text { number reached } \\
39,793 \text { cases. East } \\
\text { Java followed with } \\
\text { an additional } 362 \\
\text { cases and the }\end{array}$ & $\begin{array}{l}\text { In this article, the } \\
\text { Task Force draw up } \\
\text { the news with } \\
\text { emphasis on } \\
\text { recovery-related } \\
\text { information. As } \\
\text { seen in the first } \\
\text { three paragraphs } \\
\text { that focus on } \\
\text { improving recovery } \\
\text { rates and the } \\
\text { number of people } \\
\text { tested. }\end{array}$ & $\begin{array}{l}\text { By putting the } \\
\text { recovery rate as the } \\
\text { headline, the Task } \\
\text { Force shows that } \\
\text { they want the } \\
\text { readers to see the } \\
\text { high recovery rate } \\
\text { first compared to } \\
\text { the additional } \\
\text { positive numbers so } \\
\text { that the public } \\
\text { doesn't feel worried } \\
\text { about the pandemic, } \\
\text { and it has been } \\
\text { handled well by the } \\
\text { government. }\end{array}$ \\
\hline
\end{tabular}


reached 29,924 .

Source: Covid19.go.id

Indonesia's COVID-19 Recovery Rate is Above the World Average (1 September 2020)

In the categorization aspect, it is emphasized in the title and by using the arrangement of the news text starting from good news first. From the start of the headline "Indonesia's COVID-19 Recovery Rate Above the World Average," shows that the COVID-19 Handling Task Force only summarizes the news by leaning on news related to recovery. In addition, in the lead or the first paragraph of the news, "The number of active cases in Indonesia is still better than the world average, seen as of 1 September 2020. In Indonesia the number is 42,009 cases with a percentage of $23.7 \%$, while the world average is at $26.6 \%$. "

In fact, on that day the development of positive cases of COVID-19 on a weekly basis, there was an increase of $32.9 \%$. Then, the percentage of deaths was recorded at 7,505 cases or $4.2 \%$, or higher than the world average of $3.34 \%$. Then, in the case of death there was also a quite high weekly increase, up to $24.4 \%$.

This shows, when there is news that should be worrying and can encourage people to be more aware of the spread of the Corona Virus, which is additional positive patients and high death cases, the COVID-19 Handling Task Force is leaning towards news of recovery. This is in accordance with the categorization aspect in framing according to Murray Edelman which is carried out by using certain words so that a reality can be understood. Categorization can also be a simplification, where a complex and many-dimensional reality is understood and emphasized on one side so that other dimensions of one event or fact are not covered.

In the ideological aspect, the COVID-19 Handling Task Force as the government party in charge of regulating, monitoring and handling the pandemic, writes good news about the number of recovery rate first before providing news and data for the bad news that only starts in the fourth or fifth paragraph section. For example, in the words "Then, for the current death rate, the number of deaths is 7,505 cases or $4.2 \%$, and the world average is $3.34 \%$. "So the condition (death) in Indonesia is still higher than the world average." and "For the development of positive cases of COVID-19 on a weekly basis, there was an increase of $32.9 \%$.

There are 5 provinces with the highest increase including West Java more than 100\%,
Central Java up 56.4\%, East Kalimantan up $39.2 \%$, DKI Jakarta rose $36.9 \%$, and East Java increased 20.8\%". Both sentences are written in the fifth and seventh paragraphs of press releases, or are considered as additional information only. In accordance with the ideology in Edelman's framing that ideology is a set of categories created and false awareness where the dominant group uses to dominate other groups that are not dominant, this arrangement of writing can create false awareness in the community, who think that COVID-19 is not dangerous and has been handled well.

In the rubrics aspect the COVID-19 Handling Task Force determines how to explain a phenomenon. In both articles, the news is organized from good news to bad news. In fact, in writing news based on journalistic guidelines, it is better to adhere to an inverted pyramid pattern. The main information presented must be in the first paragraph (head of the news) and it is sufficient to answer all $5 \mathrm{~W}$ $+1 \mathrm{H}$ questions (What, Where, Who, When, Why + How), meanwhile the next paragraph contains an explanation in the body and tail of the news (Fauzi, 2019). This is in line with the rubrics aspect according to Edelman, to determine how phenomena should be explained. By putting news related to recovery in the first paragraph, making the audience's view follow what the media says about the news in that column, that many COVID-19 patients have recovered, and the COVID-19 Handling Task Force wants readers to understand this. In fact, the number who recovered has not been able to catch up with the number of patients who have been confirmed positive or have not sloped.

Then, in the classification aspect, the COVID-19 Handling Task Force classifies news related to recovery as the most important news and makes the additional number of cases and deaths only as additional information. In fact, news with this classification determines and influences the emotions of the audience when seeing an event. With news like this, it makes people relax in facing the pandemic, and it is even more difficult to comply with government regulations regarding activity and mobility restrictions when the capacity of hospital isolation rooms and ICUs can treat COVID-19 patients at that time, based on data 
The COVID-19 Handling Task Force itself has almost reached 80 percent.

\section{Recovered Patients Reached 152,458 Cases (12 September 2020)}

In the categorization aspect, it is highlighted in the title "Recovered Patients Reaching 152,458 Cases" and in the first paragraph of the press release "The recovery of COVID-19 patients as of 12 September 2020 has increased by 2,241 cases. The total number of recovered patients nationally has now reached 152,458 cases". The COVID-19 Handling Task Force uses the same news text arrangement pattern, starting from good news first to bad news.

In fact, the fact that on that day there was news that should be worrying and could encourage people to be more aware of the spread of the Corona Virus, namely the addition of new positive patients that day touched 3,806 cases and the cumulative reached 214,746 cases, and 106 cases died and the total reached 8,650 cases. This is in accordance with the aspect of categorization in framing, according to Murray Edelman, where the COVID-19 Handling Task Force emphasizes issues on one side or dimension so that other dimensions of one event or fact are not covered.

In the ideological aspect, the COVID-19 Handling Task Force writes about the addition of new positive patients and deaths in the second paragraph only as a description of the first paragraph, while the detailed explanation is in the fifth paragraph. In accordance with the ideology in Edelman's framing, this arrangement of writing can create false awareness in society.

Furthermore, in the rubrics aspect, the COVID-19 Handling Task Force continues to use the same pattern in compiling the latest news for additional COVID-19 cases, when news compiled from good news to bad news. For example, the issue of the daily additional number of COVID-19 cases is almost double the number of recoveries, namely 3,806 new cases compared to 2,241 recoveries, it is precisely put in the fifth paragraph. By putting news related to recovery in the first paragraph, making the public view follow what the media said about the news in the rubric that many COVID-19 patients have recovered, even though the number who have recovered has not been able to catch up with the number of confirmed positive patients or have not sloped.

Then, in the classification aspect, the COVID-19 Handling Task Force put the recovery rate at the top and made headlines. The COVID-19 Handling Task Force shows the hope that readers will see a high recovery rate first compared to additional positive numbers so that people do not feel worried about a pandemic, and have been handled properly by the government.

Table 3. COVID-19 Handling Task Force Press Releases on October 2020

\begin{tabular}{|c|c|c|c|c|}
\hline Title & Categorization & Ideology & Rubrics & Classification \\
\hline $\begin{array}{l}\text { Patients Recovered } \\
\text { Pass the Figures } \\
225,052 \text { Cases }(03 \\
\text { October 2020) }\end{array}$ & $\begin{array}{l}\text { - Title: "Patients } \\
\text { Recovered Pass the } \\
\text { Figures 225,052 } \\
\text { Cases". } \\
\text { - Lead: "From the } \\
\text { data from the } \\
\text { Ministry of Health } \\
\text { as of October 3, } \\
\text { 2020, the number of } \\
\text { recovered patients } \\
\text { continues to } \\
\text { increase. Today } \\
\text { alone, patients } \\
\text { recovering from } \\
\text { COVID-19 have } \\
\text { increased by } 3,712 \\
\text { cases. With the } \\
\text { cumulative number, } \\
\text { it has reached } \\
225,052 \text { cases. }\end{array}$ & $\begin{array}{l}\text { - Paragraph 2: The } \\
\text { highest daily } \\
\text { recovery increase } \\
\text { came from DKI } \\
\text { Jakarta, amounting } \\
\text { to } 1,188 \text { cases and } \\
\text { the cumulative } \\
\text { number exceeded } \\
63,197 \text { cases. }\end{array}$ & $\begin{array}{l}\text {-Statement: "The } \\
\text { recovery rate in } \\
\text { DKI Jakarta, which } \\
\text { is predicted to be } \\
1,188 \text {, is still less } \\
\text { than the number of } \\
\text { additional daily } \\
\text { cases of } 1,265 \\
\text { cases." }\end{array}$ & $\begin{array}{l}\text { The Task Force put } \\
\text { the numbers of new } \\
\text { cases and deaths in } \\
\text { the final paragraph } \\
\text { to direct its readers } \\
\text { that the news } \\
\text { regarding } \\
\text { additional positive } \\
\text { cases and deaths is } \\
\text { no more important } \\
\text { than the number of } \\
\text { people who recover. }\end{array}$ \\
\hline $\begin{array}{l}\text { COVID-19 Testing } \\
\text { Results Show } 86 \% \\
\text { Confirmed }\end{array}$ & $\begin{array}{lr}\text { - Title: } & \text { COVID-19 } \\
\text { Testing } & \text { Results } \\
\text { Show } & 86 \%\end{array}$ & $\begin{array}{l}\text { - Statement "From } \\
\text { the } 2.5 \text { million } \\
\text { people who were } \\
\text { examined, } 86 \%\end{array}$ & $\begin{array}{l}\text { - Statement: "The } \\
\text { result is said to be a } \\
\text { form of tracing or } \\
\text { case tracking efforts }\end{array}$ & $\begin{array}{lr}\text { Paragraph } & 7: \\
\text { Meanwhile, for } \\
\text { treatment efforts, } \\
289,243 \quad \text { patients }\end{array}$ \\
\hline
\end{tabular}




\begin{tabular}{|c|c|c|c|c|}
\hline $\begin{array}{l}\text { Negative } \\
\text { October 2020) }\end{array}$ & $\begin{array}{l}\text { Confirmed } \\
\text { Negative } \\
\text { - Paragraph } 4 \text { : } \\
\text { "Once again we } \\
\text { would like to } \\
\text { convey our highest } \\
\text { appreciation to the } \\
\text { related officers, } \\
\text { their hard work is } \\
\text { extraordinary," } \\
\text { (Reisa } \\
\text { Brotoasmoro) }\end{array}$ & $\begin{array}{l}\text { were negative for } \\
\text { COVID-19." }\end{array}$ & $\begin{array}{l}\text { carried out by the } \\
\text { government." }\end{array}$ & $\begin{array}{l}\text { recovered. And the } \\
\text { recovery rate } \\
\text { reached } 79 \% \text { which } \\
\text { continues to be } \\
\text { increased per week. } \\
\text { This recovery rate } \\
\text { also shows an } \\
\text { increase seen per } \\
\text { week during this } \\
\text { October. }\end{array}$ \\
\hline
\end{tabular}

Source: Covid19.go.id,

Patients Recovered Pass the Figures 225,052 Cases (3 October 2020)

In the categorization aspect, it is highlighted in the title "Patients Recovered Pass the Figures 225,052 Cases" and in the first paragraph of the press release "From the data from the Ministry of Health as of October 3, 2020, the number of recovered patients continues to increase. Today alone, patients recovering from COVID-19 has increased by 3,712 cases. With the cumulative number, it has reached 225,052 cases. "The COVID-19 Handling Task Force still uses the same news text arrangement pattern, showing good news in the form of a recovery rate first.

In fact, on that day, there were 4,007 new positive patients today. The cumulative total of confirmed cases was 299,506. This is in accordance with the aspect of categorization in framing, according to Murray Edelman, where the Task Force emphasizes issues on one side or dimension so that other dimensions of one event or fact are not covered.

On the ideological aspect, the Task Force wrote about the addition of new positive patients and deaths in the fourth and seventh paragraphs. Even though the additional positive patients for the first time passed 4,000 compared to the previous month, only around 3,000 with a cumulative total of confirmed cases reaching nearly 300,000 cases. In addition, the recovery rate in DKI Jakarta, which is predicted to be 1,188 , is still less than the additional daily cases of 1,265 cases. Therefore, the writing pattern is in accordance with the ideology in Edelman's framing, the writing arrangement can create false awareness in the community.

In the rubrics aspect, the COVID-19 Handling Task Force continues to use the same pattern in compiling the latest news for additional COVID-19 cases, the news compiled from good news to bad news. For example, on the issue of additional daily COVID-19 cases, it has reached 4,000. Besides, in the previous month it was still in the range of around 3,000. By making the recovery rate the main news, it is necessary to classify that many COVID-19 patients have recovered, even though the number of positive cases is still climbing the mountain.

Then, in the classification aspect, the COVID-19 Handling Task Force put the numbers of new cases and deaths in the final paragraph to direct its readers that news related to additional positive cases and deaths is no more important than the number of people who recover. The COVID-19 Handling Task Force shows the hope that the reader sees COVID-19 being handled properly by the government.

COVID-19 Testing Results Show 86\% Confirmed Negative (19 October 2020)

In the categorization aspect, it is highlighted in the title "COVID-19 Testing Results Show 86\% Confirmed Negative" and the statement in paragraph 4 "Once again we convey our highest appreciation to the related officers, their hard work is extraordinary" by Reisa Brotoasmoro. According to the categorization aspect in framing, according to Murray Edelman, where the COVID-19 Handling Task Force emphasizes the issue on one side or dimension so that other dimensions of one event or fact are not covered.

In fact, in reality, $14 \%$ (out of 2.5 million people) were positive for COVID-19. This means that of the 10 who were tested, 8 were negative and 2 were positive. This figure is far from the 5 percent minimum threshold for positivity rate set by the World Health Organization (WHO) standard (Iqbal, 2021). The maximum positivity rate of 5 percent set by WHO will never be known or become knowledge related to the pandemic by readers, so that the data will only be a number and ignored by the public. 
In the ideological aspect, the COVID-19 Handling Task Force wrote the statement "Of the 2.5 million people who were examined, $86 \%$ of them were negative COVID-19." In fact, according to WHO recommendations there should be $95 \%$ of people who are healthy or not infected with COVID-19 at one time. Therefore, the writing pattern is in accordance with the ideology in Edelman's framing, the writing arrangement can create false awareness in the community.

In the rubrics aspect, the COVID-19 Handling Task Force emphasized the government's performance in encouraging the number of negative people for COVID-19 as much as 86 percent through the statement "86 percent of the results were a form of tracing efforts or tracking cases carried out by the government". It seems like it wants to show and direct the view of the public to follow what is said that the government has succeeded in handling it.

Then, in the classification aspect, the COVID-19 Handling Task Force emphasizes at seventh paragraph, that for treatment efforts there are 289,243 patients recovered and the recovery rate or recovery rate reached $79 \%$ which continues to be increased per week. In fact, Indonesia's test figures are still far from the WHO target for that period. With this classification, the Task Force shows that readers hope that COVID-19 has been handled properly.

Table 4. COVID-19 Handling Task Force Press Releases on November 2020

\begin{tabular}{|c|c|c|c|c|}
\hline Title & Categorization & Ideology & Rubrics & Classification \\
\hline $\begin{array}{l}\text { The Number of } \\
\text { Recovered Patients } \\
\text { COVID-19 } \\
\text { Continues to } \\
\text { Increase to } 429,807 \\
\text { People (25 } \\
\text { November 2020) }\end{array}$ & $\begin{array}{l}\text { - Title: The Number } \\
\text { of Recovered } \\
\text { Patients COVID-19 } \\
\text { Continues r to } \\
\text { Increase to } 429,807 \\
\text { People }\end{array}$ & $\begin{array}{l}\text { - Lead: Today's } \\
\text { additions continue } \\
\text { to increase the } \\
\text { cumulative } \\
\text { recovery rate to } \\
429,807 \text { people or } \\
84.0 \%\end{array}$ & $\begin{array}{lr}\text { Paragraph } & 3: \\
\text { Breakdown per } \\
\text { province begins } \\
\text { with the news of } \\
\text { recovery }\end{array}$ & $\begin{array}{l}\text { The emphasis on } \\
\text { cured cases was } 84 \\
\text { percent. }\end{array}$ \\
\hline $\begin{array}{l}\text { Number of } \\
\text { Week }\end{array}$ & $\begin{array}{l}\text { - Title: Number of } \\
\text { Testing Week Third } \\
\text { November } \\
\text { Approach WHO } \\
\text { Standard }\end{array}$ & $\begin{array}{l}\text { - Statement: In the } \\
\text { third week of } \\
\text { November 2020, } \\
\text { testing has reached } \\
\text { around } 239 \\
\text { thousand or } 88.6 \\
\text { percent. } \\
\text { - Statement: "This } \\
\text { is the highest } \\
\text { number we have } \\
\text { ever reached." }\end{array}$ & $\begin{array}{l}\text { - Lead: "Please } \\
\text { note, the standard } \\
\text { number of tests per } \\
\text { area is adjusted to } \\
\text { the population } \\
\text { density in it." }\end{array}$ & $\begin{array}{l}\text { - Statement: The } \\
\text { government is still } \\
\text { pursuing the } \\
\text { achievement of } \\
\text { COVID-19 testing } \\
\text { numbers }\end{array}$ \\
\hline
\end{tabular}

Source: Covid19.go.id

The Number of Recovered Patients COVID-19 Continues to Increase to 429,807 People (25 November 2020)

Different from the previous COVID-19 Handling Task Force reports that predicted a cure rate, in November the COVID-19 Handling Task Force began balance the detailing about the recovery rate with the number of new cases and deaths due to Covd19. However, directing readers to information related to healing is still being done. In a press release on November 25, 2020, the title emphasizes on healing, as well as the news lead which begins with data on COVID-19 recovered patients, which increased by 4,494 people and the cumulative reached 429,807 people or $84 \%$ of cumulatively confirmed cases.
In fact, on that day the addition of confirmed positive patients daily again increased to around 5,000 or to be precise an increase of 5,534 cases so that the cumulative cases had reached 511,836 cases. This explanation, in this press release, is indeed placed in the first paragraph but only as a complement to information on recovery numbers. This is in accordance with the categorization aspect in framing, according to Murray Edelman, where the COVID-19 Handling Task Force still practices pressing issues on one side.

In the ideological aspect, the COVID-19 Handling Task Force wrote about the addition of a cumulative cure of 429,807 people or $84.0 \%$. This statement seems to rule out that the positivity rate or the number of people who are 
positive for COVID-19 compared to the number of people tested daily in Indonesia has actually increased from 14 percent in October to around 15-16 percent per day, on the other hand testing is also sloping, especially in regions and on holidays such as Saturday and Sunday (Iqbal, 2021). Therefore, the writing pattern is in accordance with the ideology in Edelman's framing, the writing arrangement can create false awareness in the community.

From the rubrics aspect, the COVID-19 Handling Task Force still applies the writing pattern of providing good news, namely the recovery rate as the main news and the additional number of cases and deaths as additional or explanatory information with details of cases per province starting with the news of recovery. It is like wanting to show and direct the view of the audience to follow what was said that the cure rate was high. Even though the daily number of cases has reached 5,000 per day and the cumulative has exceeded 500,000 cases.

Then, in the classification aspect, it is also carried out in the initial paragraph by emphasizing that the cure rate is already $84 \%$. With this classification, the COVID-19 Handling Task Force shows the hope that the reader is aware of the success of the handling of the government, which indeed shows that it is higher than in previous months. However, the fact is that the death rate and new cases also go hand in hand, continue to rise and even spike (Syakriah, 2020).

\section{Number of Testing Week Third November Approach WHO Standard (24 November 2020)}

Just as in the previous press release writing pattern, the COVID-19 Handling Task Force uses a method of writing good news first and then bad news. However, this method makes the COVID-19 Handling Task Force seem to cover up the bad news that exist in additional cases and handling of COVID-19 in Indonesia.

Based on the categorization aspect, on November 24 the COVID-19 Handling Task Force wrote a press release with "Number of Testing Week Three November Approaches WHO Standards". In the title and the article as a whole, readers are directed to know that the handling of COVID-19 in Indonesia is reaping achievements, because testing 100 percent of the population in an archipelagic country is not easy. The title fits the categorization aspect in framing according to Murray Edelman, where the COVID-19 Handling Task Force still practices pressing issues on one side and tends to ignore that the COVID-19 case at the end of November 2020 is increasing, which is also a result of high levels of testing, and also test any uneven areas.

For the ideological aspect, two statements were "In the third week of November 2020, the testing carried out had reached around 239 thousand or 88.6 percent." and "This is the highest number we've ever reached." This could lead to an interpretation that the government has tested quite a lot of COVID-19 in the community, even though the facts are as stated by Epidemiologist Masdalina Pane (on Ayu, 2020), that COVID-19 testing was uneven, only concentrated in DKI Jakarta and East Java. This is not clearly stated in the COVID-19 Handling Task Force press release agency. The writing of this statement can create false awareness in the public that thinks that the government's handling of COVID-19 is evenly distributed according to the ideology in Edelman's framing of the composition of the writing.

In the rubrics aspect, the COVID-19 Handling Task Force wrote "Please note, the standard number of tests per area is adjusted to the population density in it". This leads the audience to follow what is said that the level of the COVID-19 test in Indonesia has almost been fulfilled, especially with the information in the next paragraph explaining that out of 267 million people, testing of 267,000 people is required per week and in the third week of November 2020 However, the testing carried out has reached around 239 thousand or 88.6 percent, although in fact the tests carried out are only centered in DKI Jakarta and East Java, such as in the aspect of Edelman's framing rubrics.

On the classification aspect, the COVID19 Handling Task Force wrote a statement "The government is still pursuing the achievement of the COVID-19 testing number" at the beginning. With this statement, the COVID-19 Handling Task Force conducted a classification and showed the readers' hope of realizing that the government had achievements in handling COVID-19. Even though the fact is that overall fluctuations in the number of testing still occur which are influenced by various things, such as holiday conditions, number and capacity of laboratories, human resources for health workers, availability of reagents and also Indonesia's geographical conditions. However, the Task Force explained this in the fifth paragraph or just as additional information. 


\section{Conclusion}

Based on the results of the analysis, the findings of the study concluded that the COVID-19 Handling Task Force succeeded in compiling a self-image that the government had handled COVID-19 well and successfully, and did not frighten the public with bad news related to COVID-19, thus forming an understanding in the community that handling COVID-19 in Indonesia has been successful.

In its articles, the COVID-19 Handling Task Force conducts framing according to Murray Edelman's framing analysis with 4 aspects (categorization, ideology, rubrics, and classification). First, from the categorization of the Task Force to construct its role in handling COVID-19 as good and correct by highlighting news related to recovery and highlighting big pictures or big numbers first and putting aside bad news at the end or just as an explanation. Furthermore, the COVID-19 Handling Task Force instilled ideology by directing the public's view of the success of the government's COVID-19 handling, through statements regarding government achievements, such as the level of tests that nearly reached the target, high recovery, high negative test numbers, and without ever mentioning about bad news that happened, such as a surge in cases that rose by around 100,000 every month and even every two weeks.

Then, from the rubrics in the COVID-19 Handling Task Force press releases as well, according to its objectives, the COVID-19 Handling Task Force created a false understanding so that people would not be afraid and pressured to face the pandemic. So that the public's compliance to carry out health protocol by wearing masks, washing hands, and maintaining distance, was loosens up by the end of 2020, unlike the success of suppressing additional COVID-19 cases that occurred in the implementation of social restrictions in March 2020.

In line with the categorization, the COVID-19 Handling Task Force also clearly classified it by emphasizing and highlighting good news. When viewed from the entire Covid19.go.id website, the Task Force tends to write about the achievements of the government and never make news with bad news.

\section{References}

Ahern, K. R., \& Sosyura, D. (2014). Who Writes the News? Corporate Press Releases during Merger Negotiations Published by: Wiley for the American Finance
Association Stable

$U R L:$

https://www.jstor.org/stable/43611061

Who Writes the News? Corporate Press

Releases during Merger Negotiations. 69(1), 241-291.

Akil, M. A. (2014). Regulasi Media di Indonesia (Tinjauan UU Pers dan UU Penyiaran). Jurnal Dakwah Tabligh, 137145.

https://doi.org/https://doi.org/10.24252/jdt .$v 15 i 2.344$

Alvin, S. (2020). Strategi Komunikasi Politik Juru Bicara Wakil Presiden Jusuf Kalla ( JK) 2014-2019 sebagai Humas Pemerintah. Jurnal Komunikasi Trunojoyo, 14(1), 43-62.

Aryadi. (2014). Framing Analysis in Media Television News MetroTVOne Related Arrest by the Chairman MK Akil Mocktar Commission Case of Corruption. Jurnal The Messenger: Cultural Studies, IMC, and Media, 6, 58-65. https://doi.org/http://dx.doi.org/10.26623/t hemessenger.v6i2.193

Asteria, D. (2014). Pembingkaian Gaya Hidup Sehat dalam Pemanfaatan Konvergensi Media. Jurnal Komunikasi Indonesia, 13, 51-64.

https://doi.org/https://doi.org/10.7454/jki. v3i1.7847

Ayu, R. (2020). Epidemiolog Akui Testing COVID-19 Belum Merata, Terbanyak di DKI Jakarta dan Jatim. Retrieved January 24, 2021, from TribunNews.com website: https://www.tribunnews.com/corona/2020 /11/18/epidemiolog-akui-testing-COVID19-belum-merata-terbanyak-di-dkijakarta-dan-jatim

Covid19.go.id. (2020a). Hasil Testing COVID19 Menunjukkan 86\% Terkonfirmasi Negatif.

Covid19.go.id. (2020b). Jumlah Testing Pekan Ketiga November Dekati Standar WHO.

Covid19.go.id. (2020c). Pasien Sembuh COVID-19 Jumlahnya Terus Meningkat Menjadi 429.807 Orang.

Covid19.go.id. (2020d). Pasien Sembuh Mencapai 152.458 Kasus.

Covid19.go.id. (2020e). Tingkat Kesembuhan COVID Indonesia di Atas Rata-Rata Dunia.

Fathururrahim, M. F. (2017). Analisis Framing Murray Edelman: Berita Aksi Damai 411 di Surat Kabar Republika Edisi 5 - 7 November 2016.

Fauzi. (2019). Cara Menentukan Pokok Berita. Retrieved January 27, 2021, from Brainly 
website:

https://brainly.co.id/tugas/23820306

Hardian, A. (2018). Akurasi Antara Isi Siaran Pers dengan Pemberitaan Media Online Nasional Periode 2018 (Analisis Isi Siaran Pers DPP Organda). Komunika Journal of Communication Science and Islamic Da'wah, 2(2), 163-178. Retrieved from http://ejournal.uika-

bogor.ac.id/index.php/Komunika/article/v iew $/ 4641 / 2543$

Iqbal, M. (2021). Kacau! Positivity Rate COVID-19 RI 33,24\%, Standar WHO 5\%. Retrieved January 24, 2021, from CNBC Indonesia

website: https://www.cnbcindonesia.com/news/202 10124205935-4-218369/kacau-positivityrate-COVID-19-ri-3324-standar-who-5

Lambert, V. A., \& Lambert, C. E. (2012). Editorial: Qualitative Descriptive Research: An Acceptable Design. In Pacific Rim International Journal of Nursing Research.

Launa. (2020). Analisis Framing Berita Model Robert Entman Terkait Citra Prabowo Subianto Di Republika . Co . Id Robert Entman Framing Analysis Of Prabowo Subianto' S Image In Republika . Co . Id March - April 2019 Edition. Jurnal Media dan Komunikasi, 3(1), 50-64. https://doi.org/10.17933/diakom.v3i1.57

Lee, S. T., \& Basnyat, I. (2013). From Press Release to News : Mapping the Framing of the 2009 HIN1 A Influenza Pandemic From Press Release to News : Mapping the Framing of the 2009 HIN1 A Influenza Pandemic. 0236. https://doi.org/10.1080/10410236.2012.65 8550

Mark, M., Julie, L., \& Bonnie, P. (1998). Framing the Candidates in Presidential Primaries: Issues and Images in Press
Releases and News Coverage. Journalism and Mass Communication Quarterly, 75(2), 312-324. https://doi.org/https://doi.org/10.1177/107 769909807500207

Rahardjo, M. (2018). Paradigma Interpretif. Retrieved from http://repository.uinmalang.ac.id/2437/

Robbins, N. (2020). Media Framing and Female Political Candidates. DePaul University.

Rohmatullah, A. (2017). Analisis Framing Murray Edelman dalam Periwayatan Hadith bi Al-Ma'na. Jurnal Keislaman dan Humaniora, 3(2), 243-264. https://doi.org/https://doi.org/10.35719/isl amikainside.v3i2.60

Seitel, F. P. (2015). Praktik Public Relations. Jakarta: Erlangga.

Syakriah, A. (2020). Positivity rate remains high amid drop in testing, recorded cases. Retrieved January 3, 2021, from The Jakarta Post website: https://www.thejakartapost.com/news/202 0/11/10/positivity-rate-remains-highamid-drop-in-testing-recorded-cases.html

Thorne, S., Kirkham, S. R., \& Flynn, K. O. (2004). The Analytic Challenge in Interpretive Description. International Journal of Qualitative Methods, 1-11. https://doi.org/10.1177/160940690400300 101

University of Twente. (2019). Communication Theories. Retrieved from https://www.utwente.nl/en/bms/communi cation-theories/

Wang, Y., Hao, H., \& Sundahl, L. (2021). Examining risk and crisis communications of government agencies and stakeholders during early-stages of COVID-19 on Twitter. Computers in Human Behavior, 114(June 2020), 106568. https://doi.org/10.1016/j.chb.2020.106568 